Article

\title{
The Effect of Coupling Solar Thermal System and Geothermal Heat Pump Systems in Areas with Unbalanced Heating and Cooling Demand
}

\author{
Jihyun Hwang ${ }^{1,2}$, Doosam Song ${ }^{3, *}$ and Taewon Lee ${ }^{2, *}$ \\ 1 Department of Construction Environmental System Engineering, Sungkyunkwan University, Suwon 16419, \\ Korea; jhhwang0127@gmail.com \\ 2 Department of Fire Safety Research, Korea Institute of Civil Engineering and Building Technology, \\ Goyang 10223, Korea \\ 3 School of Civil, Architectural Engineering, and Landscape Architecture, Sungkyunkwan University, \\ Suwon 16419, Korea \\ * Correspondence: dssong@skku.edu (D.S.); twlee@kict.re.kr (T.L.)
}

Citation: Hwang, J.; Song, D.; Lee, T. The Effect of Coupling Solar Thermal System and Geothermal Heat Pump Systems in Areas with Unbalanced Heating and Cooling Demand. Energies 2021, 14, 31. https://dx.doi.org/

10.3390/en14010031

Received: 17 November 2020

Accepted: 21 December 2020

Published: 23 December 2020

Publisher's Note: MDPI stays neutral with regard to jurisdictional claims in published maps and institutional affiliations.

Copyright: () 2020 by the authors. Licensee MDPI, Basel, Switzerland. This article is an open access article distributed under the terms and conditions of the Creative Commons Attribution (CC BY) license (https:/ / creativecommons.org/ licenses/by/4.0/).

\begin{abstract}
Geothermal source heat pump (GSHP) systems as renewable energy systems are being more frequently installed as part of the zero-energy building drive. However, in South Korea, where a large amount of heating load can be required, maintaining high system performance by using only a GSHP is difficult owing to the gradual degradation of its thermal performance. The performance of a solar-assisted GSHP system was therefore experimentally analyzed and compared with a GSHP-only system. The results showed that the heating coefficient of performance of the GSHP-only operation was 5.4, while that of the solar-assisted GSHP operation was 7.0. In the case of the GSHP-only system, the maximum temperature of the heat pump water supply on the heat source side was initially $13.1^{\circ} \mathrm{C}$, but this rapidly decreased to $11.4^{\circ} \mathrm{C}$ during operation. For the solar-assisted GSHP system, the temperature of the water supply to the heat source side of the heat pump was controlled at $15-20.9^{\circ} \mathrm{C}$, and the power consumption for system operation was reduced by about $20 \%$ compared with that for the GSHP-only system. Much higher temperatures could be supplied when solar heat is used instead of ground heat, as solar heat contributes to the performance improvement of the heat pump system.
\end{abstract}

Keywords: geothermal source heat pump; solar thermal system; heating; coupling; performance analysis

\section{Introduction}

There is a global trend toward zero-energy buildings in order to minimize buildings' energy consumption and reduce carbon dioxide emissions. As of 2020, the South Korean government has mandated the construction of new buildings with a total floor area of $1000 \mathrm{~m}^{2}$ or more as zero-energy buildings. Zero-energy buildings are buildings that waste less energy by having improved insulation and air-tightness, and minimize energy consumption through energy production using renewable energies, such as solar and geothermal energies. It is envisaged that by 2030, all newly constructed buildings larger than $500 \mathrm{~m}^{2}$ will be zero-energy buildings, thus emphasizing the importance of new and renewable energy sources.

Solar and geothermal energies are renewable and can significantly contribute to achieving zero-energy buildings by generating energy on-site or off-site. Since 2004, the South Korean government has mandated the installation of renewable energy systems, whereby a part of a building's energy demand in terms of new construction, extension, or renovation of public buildings of equal to or larger than $1000 \mathrm{~m}^{2}$ is realized by renewable energy; this percentage increased from 10\% in 2011 to $30 \%$ in 2020. In South Korea, the installation of a geothermal heat pump system as a renewable energy system [1]. 
Geothermal systems, ground heat source systems, or ground-coupled heat pump (GCHP) systems are widely used in the USA, central and northern Europe, and northwestern China for space heating [2,3]. In addition, the application of GCHPs has increased in multi-residential building projects in South Korea [4].

Geothermal source heat pumps (GSHPs) provide heating and cooling by exchanging heat with the soil. The advantage of such a system is that soil temperature remains constant across time. The performance of GSHPs is high in the case of Toronto, Canada, where the heating and cooling loads are balanced. However, in South Korea and Edmonton, Canada, the annual heating demand is larger than the cooling demand, and thus the heating performance of GSHPs decreases with time owing to soil thermal imbalances [5]. Furthermore, room temperatures go below the set point and the GSHP does not function normally for years of operation [6]. Conventional studies show that the average ground temperature could decline by $3-12{ }^{\circ} \mathrm{C}$, and then the coefficient of performance could decline by approximately $0.50-2.20$ [7-13]. Therefore, the thermal imbalance of GSHPs in cold regions must be addressed.

Qian and Wang [8] proposed ground heat exchanger (GHE)-modified solutions, such as by increasing borehole space. A larger borehole space indicates a larger soil heatretaining ability [14]. System-modified solutions combine assistance energy with a conventional GSHP to enhance the thermal input to the ground or reduce the thermal output from the ground. The integration of gas boilers can achieve economic and energy savings over conventional GSHPs [15]. Furthermore, the coupling of solar thermal energy with GSHPs can enhance the heating performance by approximately 3.75 [16].

To help look for solutions to problems of inefficiency with GSHPs, in this study, the introduction of Section 1 described the background, necessity, domestic and international research trends, and structure of this manuscript. The experimental method was described in Section 2. Section 3 was analyzed a solar-assisted GSHP operating in the winter season in South Korea through field measurements. Section 4 summarizes the results of the analysis through field measurements.

\section{Method}

\subsection{Overview of the Target Building}

The analyzed building, located in Hwaseong City, South Korea, was completed in 2006. Table 1 lists key data of the analyzed building, which comprises steel frames and glass-wool composite panel $(100 \mathrm{~mm})$ wall structures. The building has two offices on the second floor, and the third and fourth floors were used for conducting the experiments. The total area of the building is $1725 \mathrm{~m}^{2}$, with total heating and cooling loads being 236.2 and $283.7 \mathrm{kWh}$, respectively. The heating and cooling heat source was a GSHP, the performance of which deteriorated over time.

Table 1. Key data of the analyzed building.

\begin{tabular}{|c|c|c|c|c|c|c|}
\hline & \multicolumn{2}{|c|}{ Zone } & \multirow{2}{*}{$\begin{array}{c}\begin{array}{c}\text { Area } \\
\left(\mathbf{m}^{2}\right)\end{array} \\
470\end{array}$} & \multirow{2}{*}{$\begin{array}{c}\begin{array}{c}\text { Cooling Load } \\
\text { (kWh) }\end{array} \\
111.0\end{array}$} & \multirow{2}{*}{$\begin{array}{c}\begin{array}{c}\text { Heating Load } \\
\text { (kWh) }\end{array} \\
131.5\end{array}$} & \multirow{2}{*}{$\begin{array}{c}\begin{array}{c}\text { Operation } \\
\text { Time (h) }\end{array} \\
8\end{array}$} \\
\hline 1 & & Office (1) & & & & \\
\hline 2 & $2 \mathrm{~F}$ & Office (2) & 366 & 86.4 & 102.4 & 8 \\
\hline 3 & \multirow{2}{*}{$3 \mathrm{~F}, 4 \mathrm{~F}$} & Laboratory & 510.8 & 38.8 & 49.8 & Intermitten \\
\hline 4 & & Hallway & 378.2 & - & - & - \\
\hline \multicolumn{3}{|c|}{ Total } & 1725 & 236.2 & 283.7 & \\
\hline
\end{tabular}

\subsection{System Configurations}

Figure 1 illustrates a schematic of the solar-assisted GSHP system analyzed in this study. It consists of a geothermal source heat pump system, GHE, and solar thermal collecting system comprising solar collectors, high- and low-temperature heat storage tanks, and circulation pumps. The heating medium (a mixture of water and antifreeze), 
heat storage medium (water), and GHE heating medium (a mixture of water and antifreeze) are separated through four sets of plate heat exchangers.

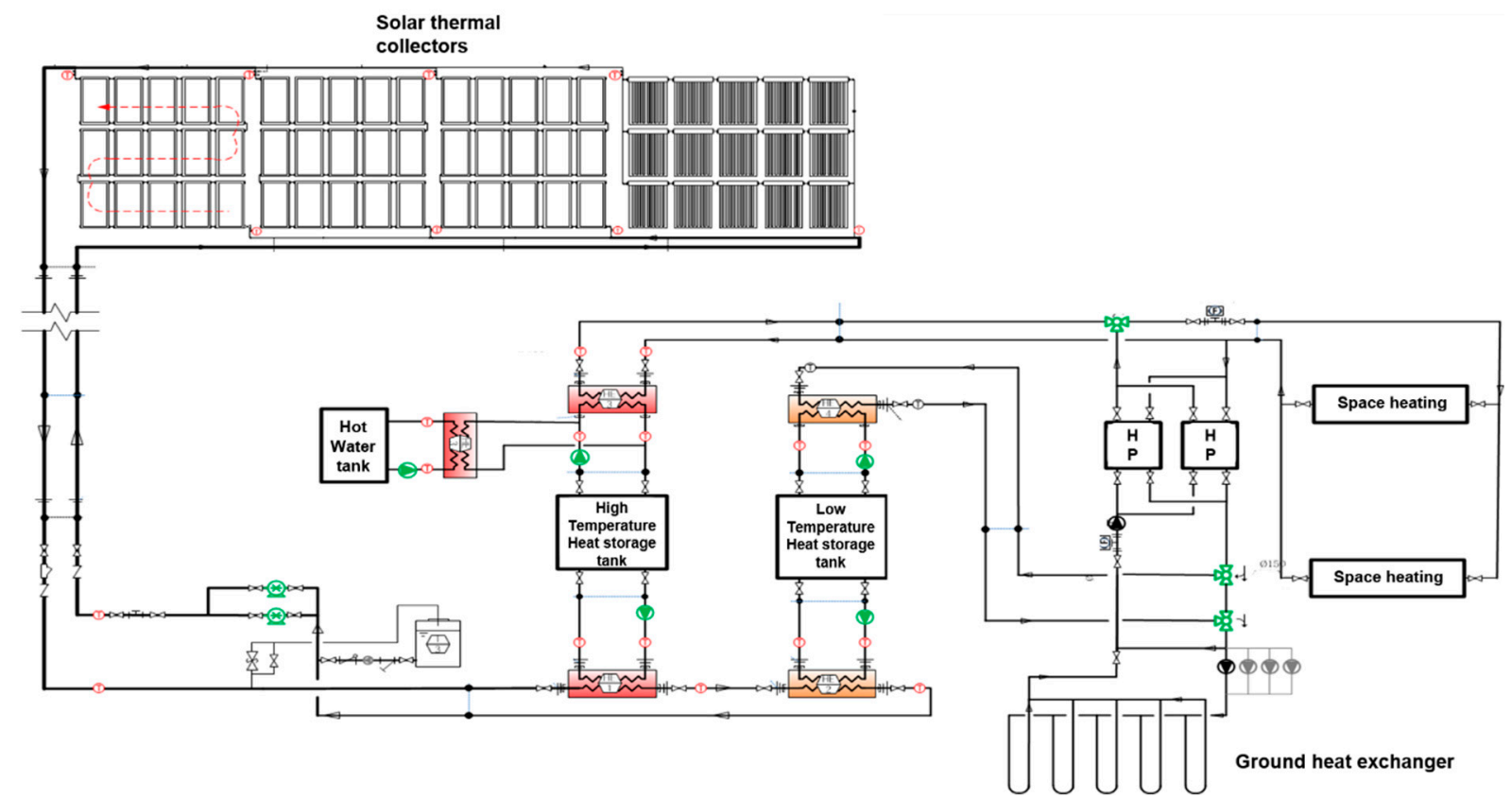

Figure 1. Schematic of solar-assisted geothermal heat pump system.

Table 2 lists the specifications of the GSHP system installed in the analyzed building. Four water-to-water heat pumps are installed, with heating capacities of 47.5 and $110.1 \mathrm{kWh}$. The total cooling and heating capacities of the four heat pumps were 262.4 and $315.1 \mathrm{kWh}$, respectively. Soil was used as the geothermal source. A closed-loop vertical GHE was used, and 29 boreholes with diameters of $150 \mathrm{~mm}$ were installed at a vertical depth of $150 \mathrm{~m}$. The total length of the GHE was $4350 \mathrm{~m}$, and the temperature of the hot water supply during heating was set to $45-48^{\circ} \mathrm{C}$.

Table 2. Specifications of the geothermal source heat pump system.

\begin{tabular}{cccccc}
\hline \multirow{2}{*}{$\begin{array}{c}\text { Geothermal Source } \\
\text { Heat Pump System } \\
\text { (Water-to-Water) }\end{array}$} & $\begin{array}{c}\text { Quantity } \\
\text { (EA) }\end{array}$ & $\begin{array}{c}\text { Cooling } \\
\text { Capacity }\end{array}$ & $\begin{array}{c}\text { Heating } \\
\text { Capacity }\end{array}$ & \multicolumn{2}{c}{$\begin{array}{c}\text { Power Consumption } \\
\text { (kW) }\end{array}$} \\
\cline { 5 - 7 }$(\mathbf{k W h})$ & & 39.1 & 47.5 & 10.1 & 14.0 \\
Heat Pump-1, & 2 & & & Cooling & Heating \\
Heat Pump-3, 4 & 2 & 92.1 & 110.1 & 25.2 & 34.9 \\
\hline
\end{tabular}

Table 3 lists the configuration of the flat-plate solar thermal collector and the doubleevacuated tube solar thermal collector that were installed to compensate for the limitation of the existing GSHP system. The thermal energy output of the flat-plate collector and evacuated tube collector and efficiency are based on the manufacturer's Korean Industrial Standards (KS) certificate [17]. 
Table 3. Classification and specification of the two solar thermal collector types.

\begin{tabular}{|c|c|c|}
\hline \multicolumn{2}{|c|}{ Classification } & Specification \\
\hline Flat-plate type & $\begin{array}{l}\text { Collector area } \\
\text { Dimensions } \\
\text { Collecting efficiency } \\
\text { Given solar gain }\end{array}$ & $\begin{array}{c}2.0 \mathrm{~m}^{2} \\
2000(\mathrm{~L}) \times 1000(\mathrm{~W}) \times 80(\mathrm{H}) \mathrm{mm} \\
71.51 \% \\
2.0 \mathrm{kWh} / \mathrm{m}^{2} \text { per day (clear-sky condition) }\end{array}$ \\
\hline $\begin{array}{l}\text { Double- } \\
\text { evacuated } \\
\text { tube type }\end{array}$ & $\begin{array}{l}\text { Collector area } \\
\text { Dimensions } \\
\text { Collecting efficiency } \\
\text { Given solar gain }\end{array}$ & $\begin{array}{c}3.02 \mathrm{~m}^{2} \\
1990(\mathrm{~L}) \times 1516(\mathrm{~W}) \times 134(\mathrm{H}) \mathrm{mm} \\
75.09 \% \\
2.6 \mathrm{kWh} / \mathrm{m}^{2} \text { per day }(\text { clear-sky condition })\end{array}$ \\
\hline
\end{tabular}

Solar collectors receive solar radiant energy and transfer it to the flowing fluid. The useful energy collected from a solar collector is given by Equation (1), and the collector efficiency is given by Equation (2) [18]:

$$
\begin{gathered}
Q_{u}=A_{c}\left[I_{T}(\sigma \tau)-U_{L}\left(T_{i}-T_{a}\right)\right] \\
E=F{ }^{\prime}(\sigma \tau)-F^{\prime} U_{L}\left[\left(T_{i}-T_{a}\right) / I_{T}\right]
\end{gathered}
$$

where, $Q_{u}$ is the useful energy gain of solar collector [W], $A_{c}$ is the collector area $\left[\mathrm{m}^{2}\right]$, $I_{T}$ is the global solar insolation at the collector plane $\left[\mathrm{W} / \mathrm{m}^{2}\right], \sigma \tau$ is the transmittance absorbance product $[-], U_{L}$ is the overall heat loss factor $\left[\mathrm{W} / \mathrm{m}^{2} \cdot{ }^{\circ} \mathrm{C}\right], T_{i}$ is the fluid inlet temperature $\left[{ }^{\circ} \mathrm{C}\right], T_{a}$ is the outdoor air temperature $\left[{ }^{\circ} \mathrm{C}\right], F^{\prime} \mathrm{m}$ is the mean temperature collector efficiency factor [-], and $E$ is the collector efficiency [-].

The total collector area of the flat-plate collector is 35 sheets $\times 2 \mathrm{~m}^{2}=70 \mathrm{~m}^{2}$, and its averaged collecting efficiency and useful solar heat gain are $71.51 \%$ and $2.0 \mathrm{kWh} / \mathrm{m}^{2}$ per day, respectively. Moreover, the total area of the double-evacuated tube collector is 15 sheets $\times 3.02 \mathrm{~m}^{2}=45.3 \mathrm{~m}^{2}$, and its averaged collecting efficiency and useful solar heat gain are $75.09 \%$ and $2.6 \mathrm{kWh} / \mathrm{m}^{2}$ per day, respectively.

Tanks were used for the conservation of heat energy or hot water for use when needed. One was a high-temperature heat storage tank, and the other was a low-temperature heat storage tank. The high-temperature tank (capacity 4 tons) first stored the heat obtained from the solar collectors, while the low-temperature tank (capacity 6 tons) performed secondary heat storage. The hot water in the high-temperature tank can be used for heating or hot water supply, while the hot water in the low-temperature tank can be used for the heat source of the heat pump or the heat sent to the ground through the ground heat exchanger for seasonal thermal energy storage. In the solar thermal system, the circulation pump is controlled and operated based on the difference between the outlet water temperature of the solar collector and the internal temperature (water in the tank) of the high-temperature tank.

This system can be operated in three ways, as shown in Figures 2-4. Figure 2 shows the typical existing GSHP operation mode. Figure 3 depicts the mode in which the collected solar heat is supplied to the heat pump through the low-temperature heat storage tank heat exchanger to supply the heating medium with a higher temperature to the heat source side of the GSHP. In this case, the temperature of the low-temperature (secondary) heat storage tank should be higher than that of the GHE; otherwise, the system will operate in the existing geothermal heat pump mode. Figure 4 depicts the operation mode in which solar heat is supplied to and stored in the ground as a seasonal borehole thermal energy storage system. In the absence of any demand for the collected solar heat and operation of the heat pump for cooling, such as in the pre-winter months, the heat collected by the solar thermal system is supplied to the underground space through the GHE. This improves the heat exchange efficiency of the geothermal source system during soil thermal imbalances. 


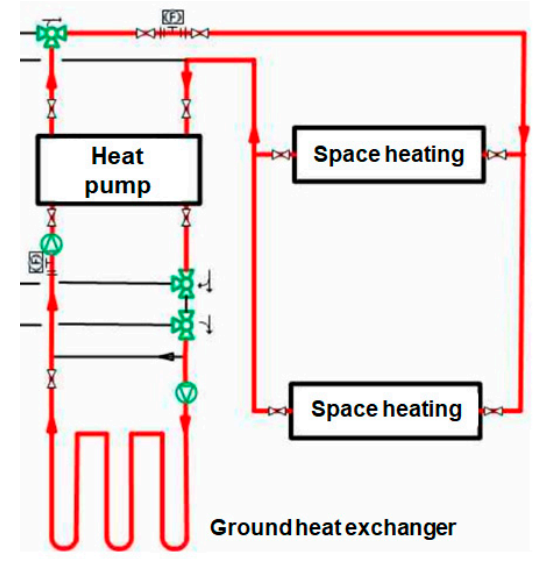

Figure 2. Geothermal-only heat pump heating operation mode.

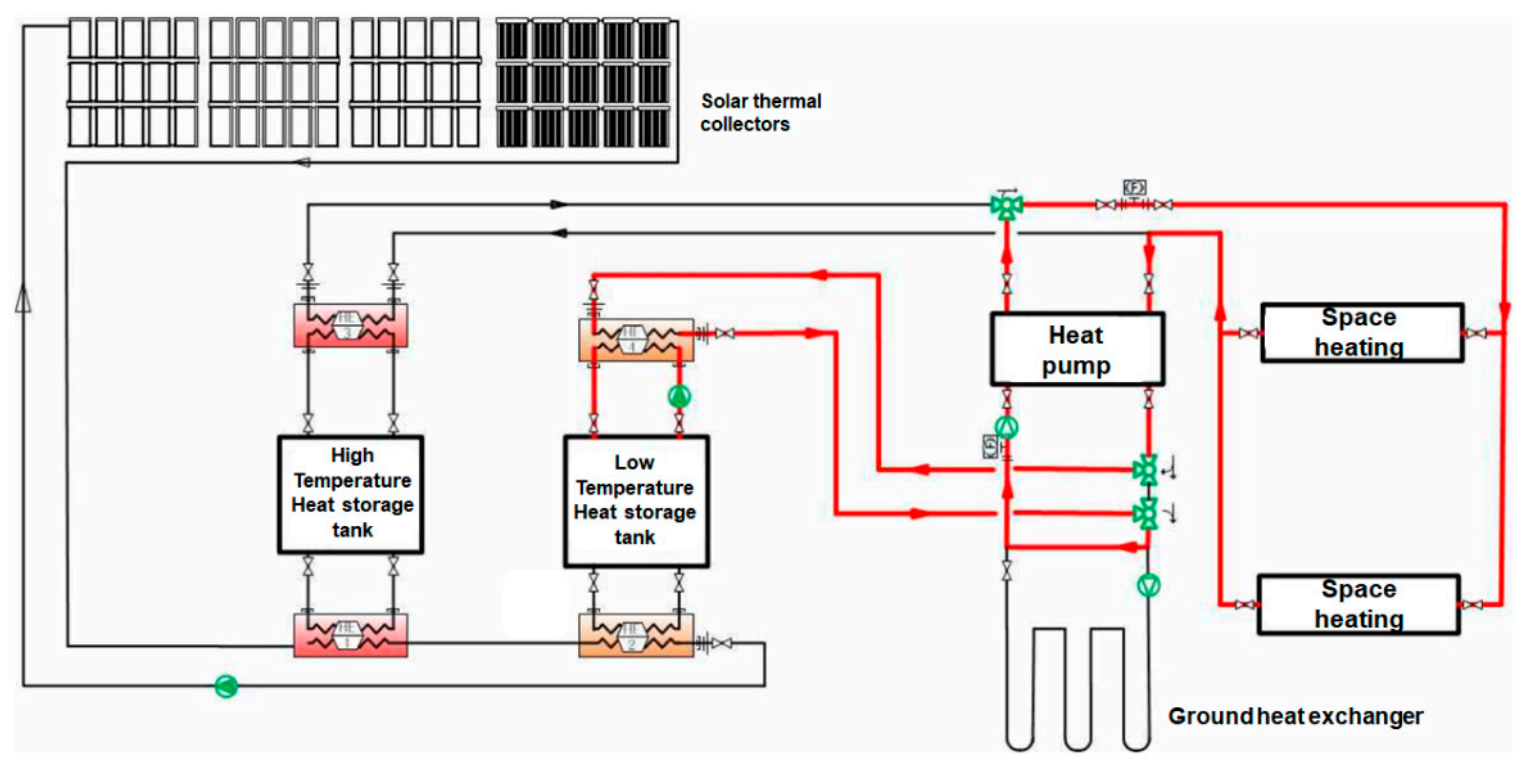

Figure 3. Collected solar heat supplied to the heat pump for space heating.

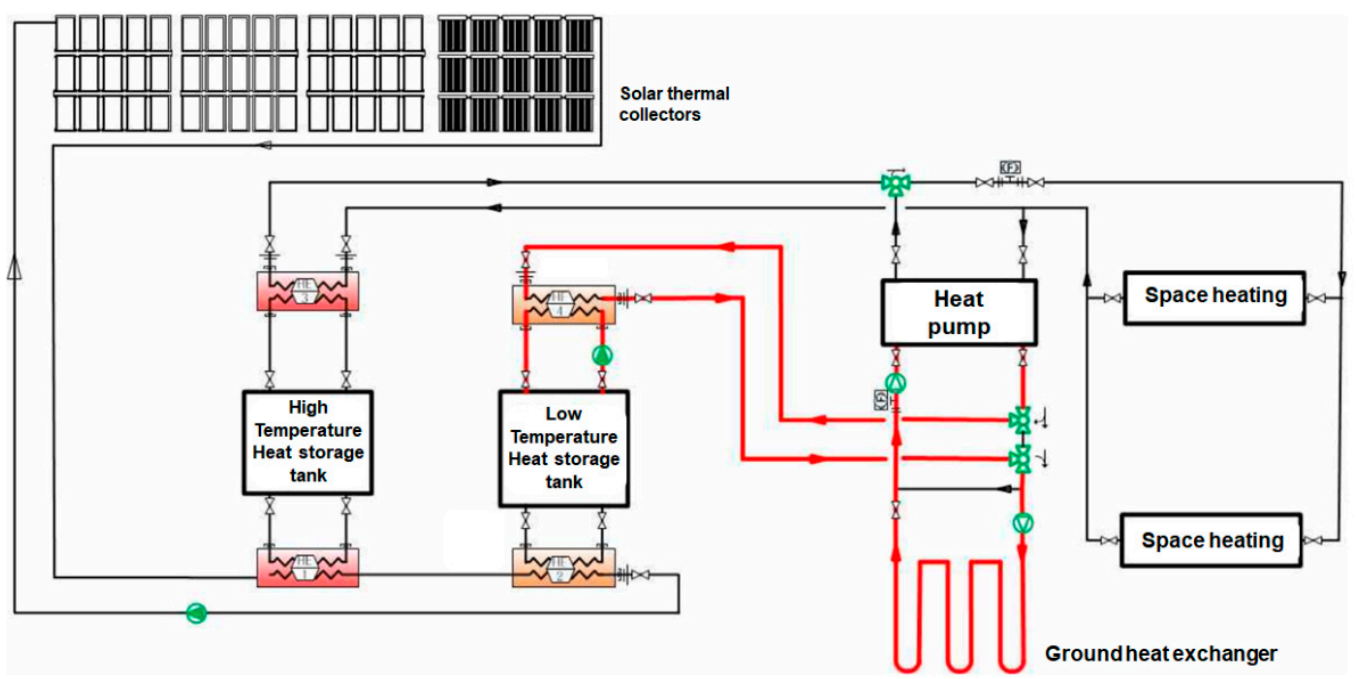

Figure 4. Collected solar heat stored in the ground storage system (seasonal borehole thermal energy storage). 
In this study, the three aforementioned operational modes were accomplished for the hybrid GSHP assisted by a solar thermal collector for the analyzed building. The performance of the solar-assisted GSHP system was analyzed for a period of 143 days, from 15 November 2019 to 6 April 2020.

The supply setting temperature on the demand side was $45{ }^{\circ} \mathrm{C}$ on the representative day when the GSHP-only was operated; the supply setting temperature on the demand side was $46.5^{\circ} \mathrm{C}$ on the representative day when the solar-assisted GSHP was operated. The outdoor air temperature and the heating load of the two systems were similar. The flow rate of the heat source and demand side uses the constant flow rate supply approach according to the operation of the circulation pumps. Solar heat collection is operated by the differential temperature control system when the temperature difference between the internal temperature of the high-temperature tank and the outlet temperature of the solar collector is $5^{\circ} \mathrm{C}$. A three-way valve was used to control the operation of the existing geothermal system and the operation of the combined system. To analyze the performance of the system, the coefficient of performance (COP) and seasonal performance factor (SPF) were used, and these are calculated by Equations (3)-(5) [10,19]:

$$
\begin{gathered}
C O P=Q_{1} / W_{1, H P} \\
C O P_{\text {system }}=Q_{1} /\left(W_{1, H P}+W_{1, \text { Pumps }}\right)
\end{gathered}
$$

where $Q_{1}$ is the heating load [kWh/day], $W_{1, H P}$ is the power consumption (heat pump) [kWh/day], and $W_{1, \text { Pumps }}$ is the power consumption (pumps) [kWh/day]

$$
S P F=Q_{2} /\left(W_{2, H P}+W_{2, \text { Pumps }}\right)
$$

where $Q_{2}$ is the heating load [ $\mathrm{kWh} /$ seasonal], $W_{2}$ is the power consumption (heat pump) $\left[\mathrm{kWh} /\right.$ seasonal], $\mathrm{W}_{2, \text { Pumps }}$ is the power consumption (pumps) [kWh/seasonal].

Table 4 displays the monitoring points of the solar thermal and geothermal systems. A total of 44 data points each in the areas comprising the solar thermal and geothermal system were monitored. To measure the temperature, the heat storage tank was equipped with a thermocouple (T type) sensor. A digital thermometer with a digital liquid crystal display was used for displaying the temperature of the geothermal heat pump supply and return to allow the overseer to directly check the temperature at the site. The manufacturer guarantees a thermometer accuracy of $\pm 0.3{ }^{\circ} \mathrm{C}\left(-60\right.$ to $\left.60{ }^{\circ} \mathrm{C}\right)$ with the thermocouple (T type) sensor and $\pm 0.15^{\circ} \mathrm{C}\left(180\right.$ to $\left.80^{\circ} \mathrm{C}\right)$ with the digital thermometer. An ultrasonic flowmeter was used to measure the flow rate. The ultrasonic flowmeter was certified as accurate to $\pm 1 \%$ (full scale). The thermometer and ultrasonic flowmeter were calibrated by the Korea Laboratory Accreditation Scheme (KOLAS), an organization that calibrates and inspects according to standards set by the International Organization for Standardization (ISO). An ELITEpro XC power metering data logger was used to measure the electric power consumption. The measurement interval was set to $1 \mathrm{~min}$, and the result files were compiled in daily units. The accuracy of the power meter was $\pm 0.06 \%$ (full scale), and it was certified by the Korea Communication Commission (KCC), which provides certification for input, output, and storage devices of data and communication messages. In the selection of the measuring devices used in this study, the appropriateness of the temperature range and flow rate range measured in this study were analyzed. All result values are values excluding the measurement equipment uncertainty so consider this part. 
Table 4. Measuring points of the solar thermal and geothermal systems.

\begin{tabular}{|c|c|c|}
\hline Items & Geothermal Source Heat Pump (GSHP) & Solar Thermal Collector \\
\hline Flow rate & $\begin{array}{l}\text { Ground heat exchangers 1, 2, } 3 \\
\text { Ground hot water supply } \\
\text { Load1 hot water supply } \\
\text { Load2 hot water return }\end{array}$ & $\begin{array}{l}\text { Solar-collector circulation } \\
\text { Solar hot water supply }\end{array}$ \\
\hline Temperature & $\begin{array}{l}\text { Ground heat } 1 \text { input, } \\
\text { Ground heat } 2 \text { input, } \\
\text { Ground heat } 3 \text { input, } \\
\text { Ground heat output, } \\
\text { HP-1A Geothermal input/output, } \\
\text { HP-1A hot water supply/return, } \\
\text { HP-1B Geothermal input/output, } \\
\text { HP-1B hot water supply/return, } \\
\text { HP-2A Geothermal input/output, } \\
\text { HP-2A hot water supply/return, } \\
\text { HP-2B geothermal input/output, } \\
\text { HP-2B hot water supply/return }\end{array}$ & $\begin{array}{l}\text { High-temp. heat source tank bottom1/bottom2, } \\
\text { High-temp. heat source tank top1/top2, } \\
\text { Low-temp. heat source tank bottom1/bottom2, } \\
\text { Low-temp. heat source tank top1/top2, } \\
\text { Collector1 input/Collector2 input/Collector3 } \\
\text { input/Collector4 input, Collector1 } \\
\text { output/Collector2 output/Collector3 } \\
\text { output/Collector4 output, Collector integrated } \\
\text { supply/return, } \\
\text { High and low temp. tank middle, } \\
\text { High and low temp. tank output, } \\
\text { High-temp. tank 1nd input/output, } \\
\text { Low-temp. tank 1nd input/output, } \\
\text { High-temp. tank 2nd input/output, } \\
\text { High-temp. tank 2nd supply/return, } \\
\text { Low-temp. tank 2nd input/output, } \\
\text { Low-temp. tank 2nd supply/return, } \\
\text { Hot water tank input/output, } \\
\text { Hot water tank return/supply }\end{array}$ \\
\hline
\end{tabular}

Main, HP-1A (compressor), HP-1B (compressor), HP-2A (compressor), HP-2B (compressor),

P4-A Pump,

Electric power consumption
P4-B Pump, P4-C Pump, P4-D Pump, P5-A

Pump, P5-B Pump, P6 A,B Pump, P7-A Pump, P7-B (S.B) Pump,

P8-A Pump, P8-B Pump, P3-A Pump, P3-B Pump
Solar 1st Pump, Solar 2nd Pump, Hot water convection pump

Outdoor temperature, Outdoor humidity, Solar Insolation

\section{Results and Discussion}

\subsection{Operation Behaviors of GSHP with and without the Solar Thermal System}

Figure 5a,b shows the operation behaviors of the GSHP without and with the solar thermal collector, respectively. To compare the performances of the two systems, the operation results obtained for a day with similar outdoor temperature conditions were selected. The changes in the heat pump source, demand-side water supply, returning-water temperature and flow rate, power consumption, and outdoor temperature were collected over time.

The power consumption was calculated as the sum of the heat and circulation pumps at the heat source and demand sides, respectively. The operation pattern of a typical heat pump system, including the intermittent operation, according to the outdoor temperature, is shown in Figure 5.

In the GSHP-only system (Figure 5a), the maximum temperature of the heat pump supply water at the heat source side was initially $13.1^{\circ} \mathrm{C}$ but rapidly decreased to $11.4^{\circ} \mathrm{C}$ during operation. The supply water temperature for heating at the demand side was maintained at approximately $45^{\circ} \mathrm{C}$, which is the set value. 


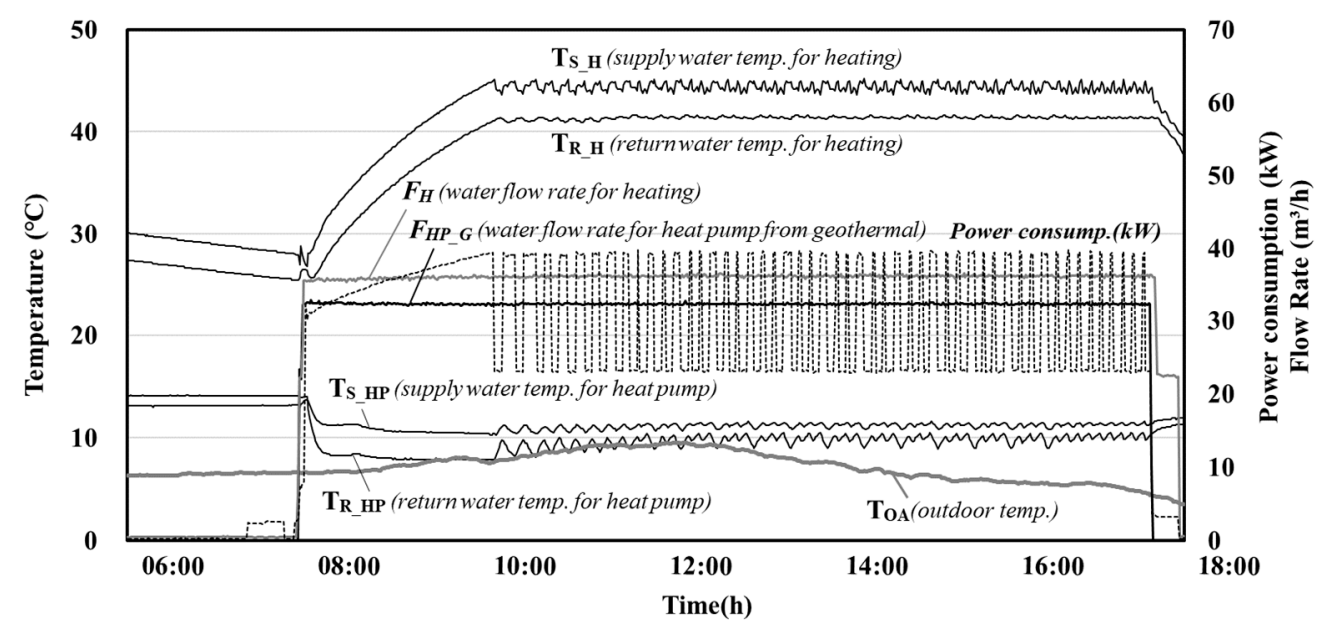

(a)

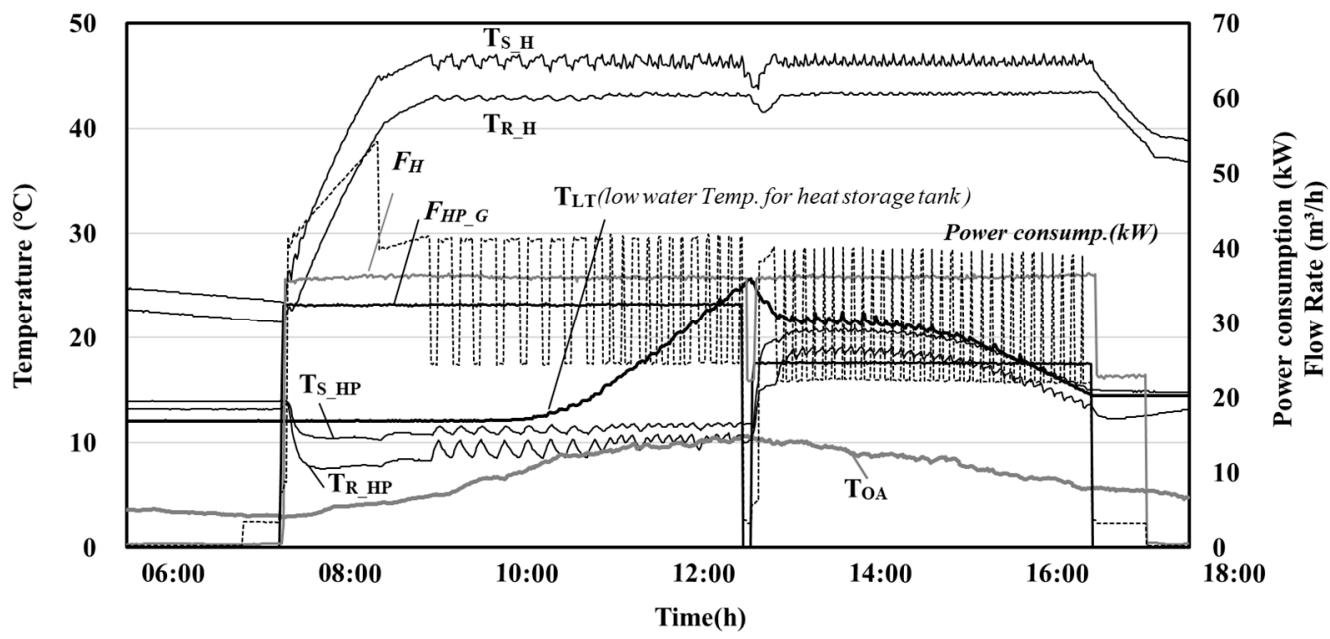

(b)

Figure 5. Operation results of the GSHP systems: (a) without and (b) with the solar thermal collector.

In the solar-assisted GSHP system, the heat source supply from the solar thermal system occurred in the afternoon because the water temperature in the low-temperature $\left(\mathrm{T}_{\mathrm{LT}}\right)$ heat storage tank was higher than that of the GHE outlet water in the afternoon. If the water temperature in the low-temperature heat storage tank was higher than $25^{\circ} \mathrm{C}$ (the setpoint temperature), the accumulated solar heat was supplied to the heat pump for heating between 13:09 and 16:54, as shown in Figure 5b. The temperature of the supply water to the heat pump source side was controlled within $15-20.9^{\circ} \mathrm{C}$. Consequently, much higher temperatures could be supplied when solar heat was used instead of ground heat; the solar heat contributes to the performance improvement of the heat pump system. The supply temperature at the demand side was $46.5^{\circ} \mathrm{C}$, which was slightly higher than that for the GSHP-only case. The solar-assisted operation required a lower power consumption because the GHE circulation pump was not required for operation.

Table 5 shows the system performance of the GSHP with and without the solar thermal system. The amount of heat supplied for heating, power consumed by the heat and circulation pumps, and COPs are listed based on the operation results in Figure 5. In the case of the solar-assisted GSHP, a slightly larger amount of heat was supplied even though the daily average outdoor temperature was slightly higher. This is because the difference of the outdoor air temperature on that day was large. In addition, the COP of the heat pump for the GHSP-only case was heating load/power consumption (heat pump) = $1431.8 \mathrm{kWh} / 265.6 \mathrm{kWh}=5.4$, while that for the system including the circulation pump was heating load / power consumption (heat pump + pumps) $=1431.8 \mathrm{kWh} /(265.6+93.4) \mathrm{kWh}$ 
$=4.0$. In contrast, the COP of the solar-assisted GSHP system was heating load/power consumption (heat pump) $=1542.5 \mathrm{kWh} / 221.1 \mathrm{kWh}=7.0$, and was $1542.5 \mathrm{kWh} /(221.1+$ 66.9) $\mathrm{kWh}=5.4$ when the circulation pump was used. These results indicate the improved performance of the solar-assisted GSHP system.

Table 5. Performance of the GSHP with and without the solar thermal collector.

\begin{tabular}{|c|c|c|c|c|c|c|c|}
\hline & \multirow{2}{*}{ Analyzed Day } & \multirow{2}{*}{$\begin{array}{l}\text { Average Outdoor } \\
\text { Air Temp. during } \\
\text { Operation } \\
\left({ }^{\circ} \mathrm{C}\right)\end{array}$} & \multirow{2}{*}{$\begin{array}{l}\text { Heating Load } \\
\text { (kWh/day) }\end{array}$} & \multicolumn{2}{|c|}{$\begin{array}{c}\text { Power } \\
\text { Consumption } \\
\text { (kWh/day) }\end{array}$} & \multicolumn{2}{|c|}{$\begin{array}{l}\text { Coefficient of } \\
\text { Performance }\end{array}$} \\
\hline & & & & $\begin{array}{l}\text { Heat } \\
\text { Pump }\end{array}$ & Pumps & $\begin{array}{l}\text { Heat } \\
\text { Pump }\end{array}$ & $\begin{array}{c}\text { Heat and } \\
\text { Circulation Pumps }\end{array}$ \\
\hline GSHP-only & 23 December 2019 & 5.0 & 1431.8 & 265.6 & 93.4 & 5.4 & 4.0 \\
\hline Solar-assisted GSHP & 31 January 2020 & 5.3 & 1542.5 & 221.1 & 66.9 & 7.0 & 5.4 \\
\hline
\end{tabular}

The temperature of the water supplied to the heat pump increased when it was coupled with the solar thermal system, and the power consumption of the circulation pump reduced as the hot water in the solar heat storage tank was directly supplied to the heat pump without traversing the relatively long GHE. The integration of the GSHP with the solar system reduced the power consumption of the heat pump by approximately $17 \%$ (GSHP-only power consumption (heat pump)-Solar-assisted GSHP power consumption (heat pump)/GSHP-only power consumption (heat pump) $=\{(265.6-221.1) \mathrm{kWh} / 265.6 \mathrm{kWh}\} \cdot 100$ $=17 \%$ ) and the pump power by approximately $28 \%$ (GSHP-only power consumption (pumps)-Solar-assisted GSHP power consumption (pumps)/GSHP-only power consumption $($ pumps $)=\{(93.4-66.9) \mathrm{kWh} / 93.4 \mathrm{kWh}\} \cdot 100=28 \%)$. Moreover, the total power consumption decreased by approximately $20 \%$. (GSHP-only power consumption (heat pump+pumps)-Solar-assisted GSHP power consumption (heat pump+pumps)/GSHP-only power consumption (heat pump + pumps $)=\{(265.6+93.4-221.1+66.9) \mathrm{kWh} /(265.6+$ 93.4) $\mathrm{kWh}\} \cdot 100=20 \%$ ).

Figure 6 shows the operation results of the solar thermal system on the analyzed day when the solar-assisted GSHP system operated. The changes in the solar collector inlet and outlet water temperatures, circulation flow rate, and temperatures of the highand low-temperature solar heat storage tanks over time, were collected along with the solar radiation and outdoor temperatures. The combined system operation started at approximately 10:00 and ended at 16:00. The total and the maximum solar radiation of the analyzed day were 604.5 and $110 \mathrm{~W} / \mathrm{m}^{2}$, respectively. The temperatures varied depending on the solar radiation, and the total amount of solar heat collected on that day was $1315.2 \mathrm{kWh}$. The amount of heat supplied to the heat pump from 13:06 when the water temperature of the solar heat storage tank exceeded $25{ }^{\circ} \mathrm{C}$ was $823.4 \mathrm{kWh}$. Approximately $63 \%$ of the collected solar heat was used as the heat source for the heat pump; this value corresponds to $38 \%$ of the total daily heating load. 


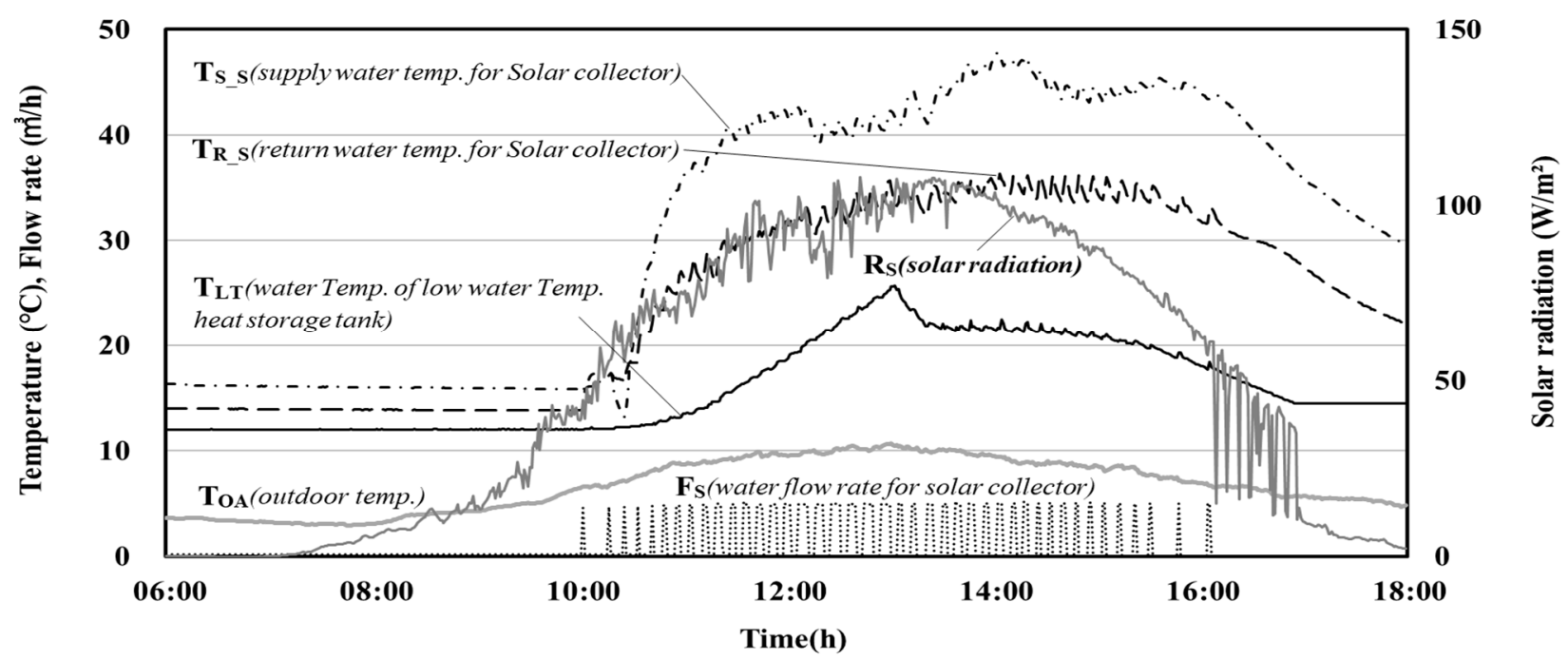

Figure 6. Operation results of the solar thermal system on the analyzed day.

Figure 7 shows the temperature variation of the supply water at the heat source side of the heat pump over time on the analyzed day when the geothermal and solarassisted operations were performed. In the case of the GSHP-only operation, the supply water temperature was approximately $11.5^{\circ} \mathrm{C}$, while in the solar-assisted operation, the temperature to the heat pump ranged from $20.9^{\circ} \mathrm{C}$ to $15^{\circ} \mathrm{C}$ with an average of $18.1^{\circ} \mathrm{C}$ during operation. The difference in the temperature between the geothermal-only and solar-assisted systems was $6.6^{\circ} \mathrm{C}$.

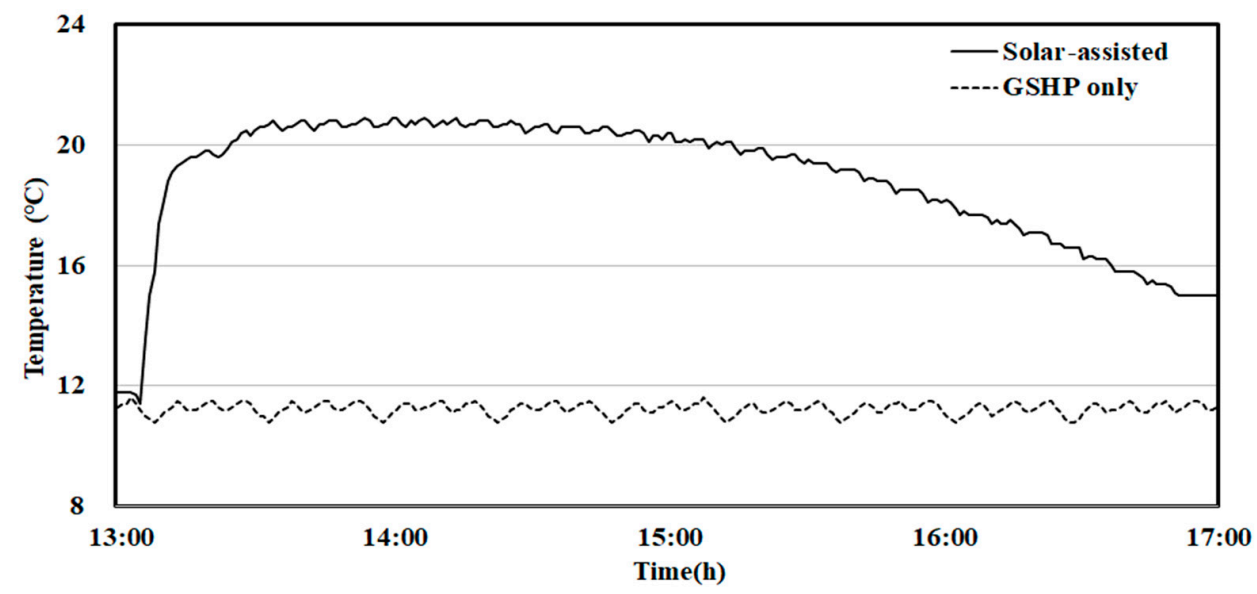

Figure 7. Supply water temperature at the heat source side of the heat pump over time on the analyzed day.

Figure 8 shows the heat supplied from the heat source to the heat pump over time on the analyzed day when both operations were performed. The amount of heat supplied was generally larger when the solar-assisted operation was performed compared with that of the GSHP-only system. Moreover, the total amount of heat supplied was 151.3 and $194.9 \mathrm{kWh}$ during the GSHP-only and solar-assisted GSHP operations, respectively, showing approximately $23 \%$ increase in heat for the solar-assisted operation. This shows an improvement in the performance of the heat pump system. 


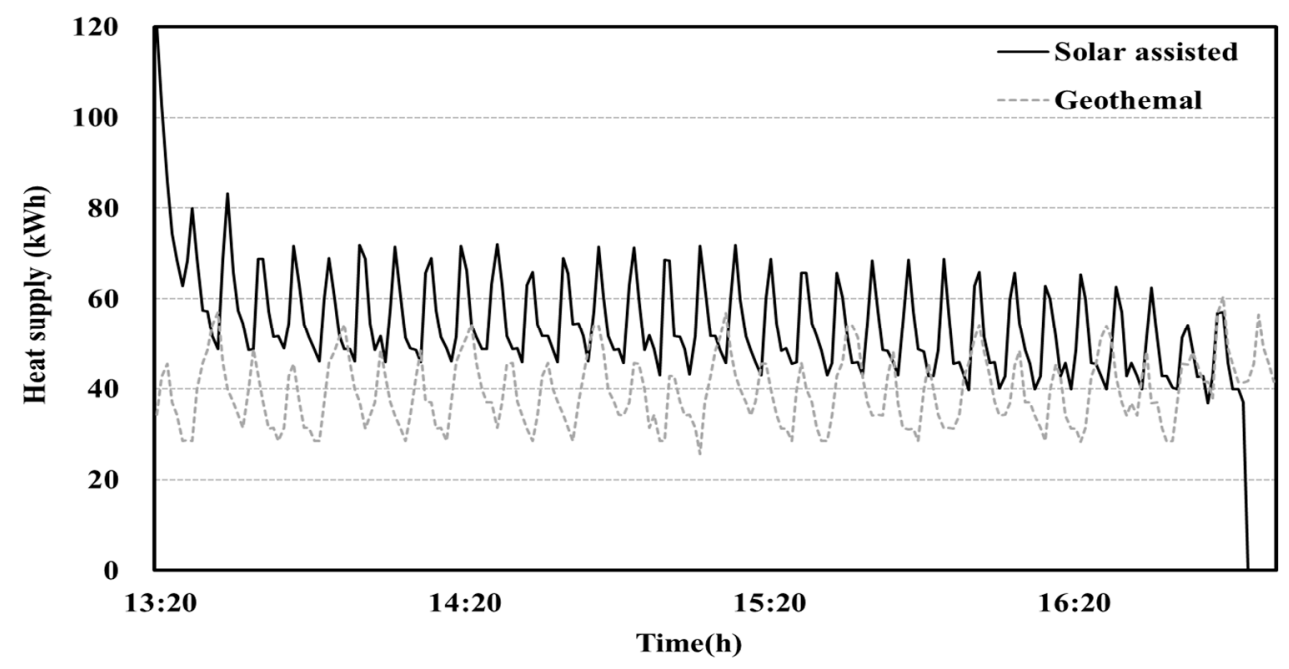

Figure 8. Amount of heat supplied to the heat source side of the heat pump.

\subsection{System Performance Analysis}

3.2.1. Influence of the Supply Temperature on Heat Pump Performance

Figure 9 shows the performance (COP) of the heat pump according to the supply temperature on the heat source side for both the GSHP-only and the solar-assisted GSHP operations. It is generally known that the inlet temperature on the heat source side of the geothermal heat pump through GHE ranges from 10 to $20^{\circ} \mathrm{C}$ during the heating operation [20].

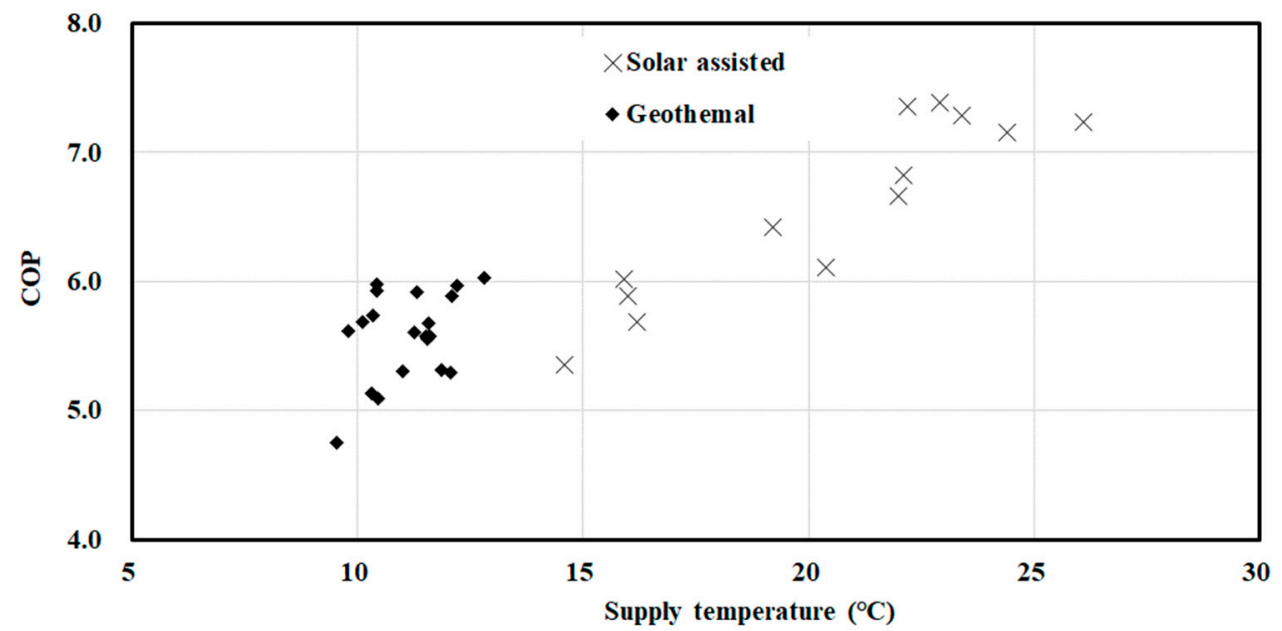

Figure 9. Heat pump performance according to the supply temperature on the heat source side for both the geothermal-only and solar-assisted operations.

The supply temperature on the heat source side ranged from 9.5 to $12.8^{\circ} \mathrm{C}$ in the case of the geothermal system operation in this study. In contrast, for the solar-assisted system operation, the temperature range was $14.6-26.1^{\circ} \mathrm{C}$.

As the supply temperature on the heat source side increased, the performance (COP) of the heat pump tended to increase almost linearly. The COP of the heat pump ranged from 4.8 to 6.0 and 5.4 to 7.4 for the GSHP-only and solar-assisted GSHP operations, respectively. In the case of the solar-assisted operation, the COP of the heat pump significantly improved.

After analyzing the seasonal performance factor (SPF) for the heating period from 15 November 2019 to 6 April 2020, the SPF for the GHSP-only case was the heating load during heating period/power consumption during the heating period (heat pump + pumps $)=29,122.6 \mathrm{kWh} /(5145.3+1893.4) \mathrm{kWh}=4.1$. In contrast, the SPF of the solar- 
assisted GSHP system was heating load during heating period / power consumption during heating period (heat pump + pumps $)=19,742 \mathrm{kWh} /(3077+982.4) \mathrm{kWh}=4.9$.

Figure 10 shows the heat supplied to the heat pump on the heat source side for both the GSHP-only and solar-assisted GSHP operations. In the case of the geothermal operation, the amount of heat supplied to the heat pump was determined in response to the heating load, while the supply temperature on the heat source side did not significantly change owing to the structural limitation of the geothermal system. In the case of the solar-assisted operation, the supply temperature varied more widely, and the amount of heat supplied could respond to the heating load.

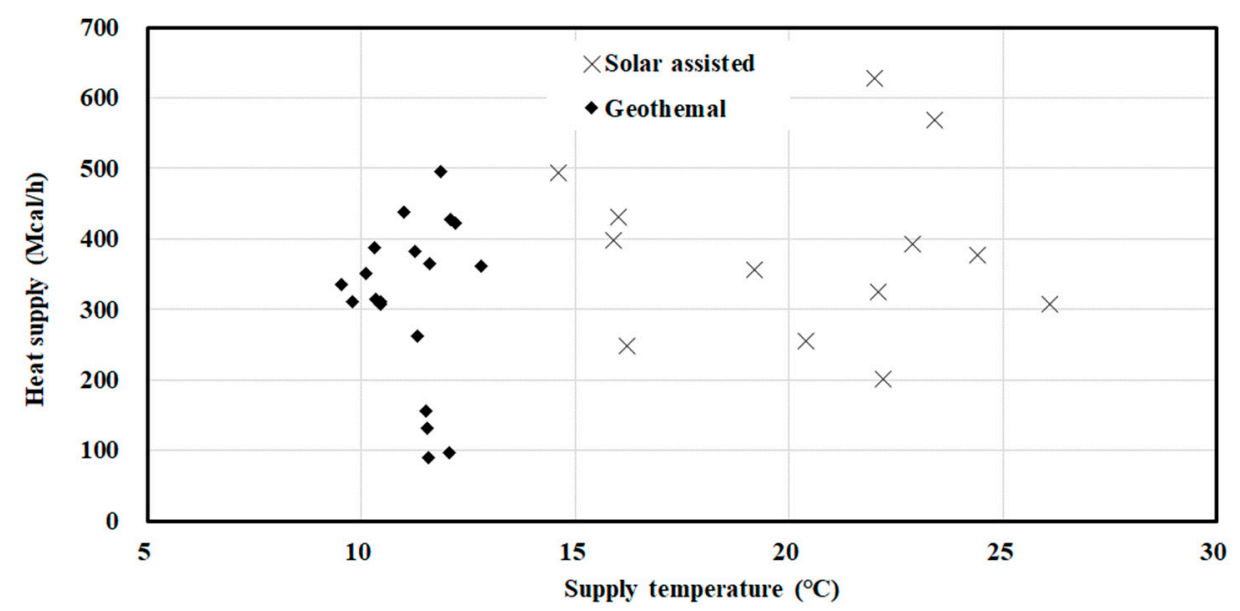

Figure 10. Heat supplied to the heat pump with the supply temperature on the heat source side for both the geothermal-only and solar-assisted operations.

The amount of heat supplied to the heat pump was not related to the supply water temperature, and it varied according to the heating load at that time.

\subsubsection{Power Consumption According to the Operation Mode}

Figure 11 shows the daily power consumption for the GSHP-only and solar-assisted GSHP operation conditions. For comparison, the daily power consumption was reviewed according to the heating load after 13:00, that is, when the daily solar heat connection operation was possible. As the daily heating load increased, the power consumption increased almost linearly, and the solar-assisted operation resulted in a lower power consumption than that in the case of the GSHP-only operation.

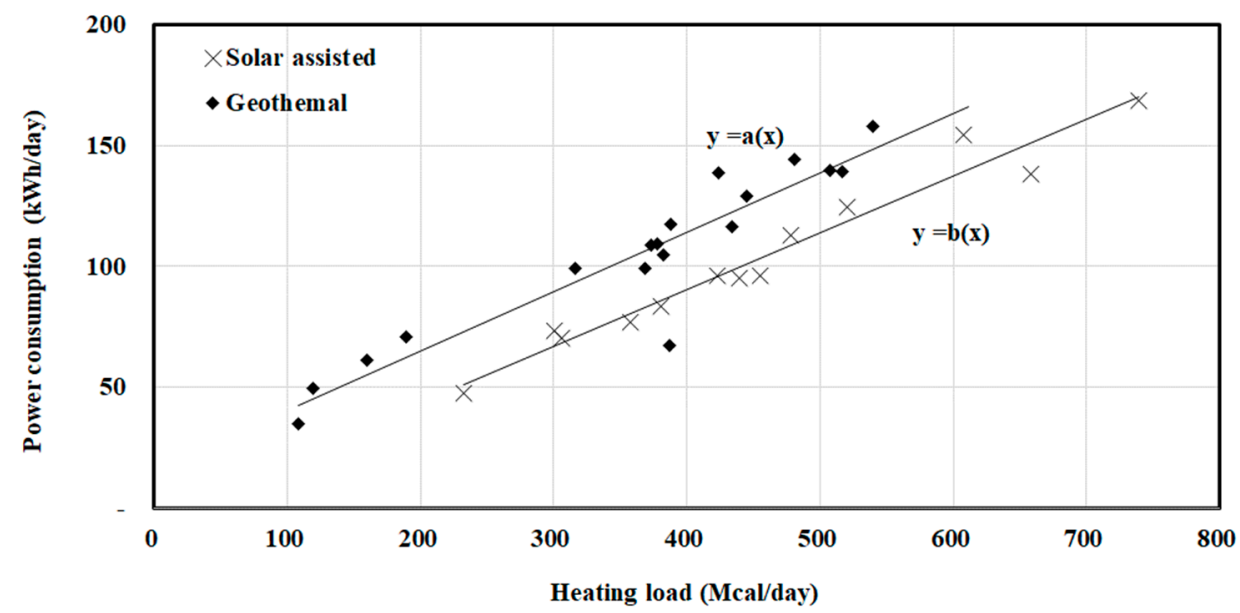

Figure 11. Power consumption according to the operation mode. 
Figure 12 shows the comparison of the average daily power consumptions in the case of the geothermal-only and solar-assisted operation conditions. The power consumption includes the consumption by the heat and circulation pumps. The annual power consumption was 58,276 kWh for the geothermal-only operation and 45,661 kWh for the solar-assisted operation. As observed, the power consumption was reduced by about $22 \%$ in the coupled operation.

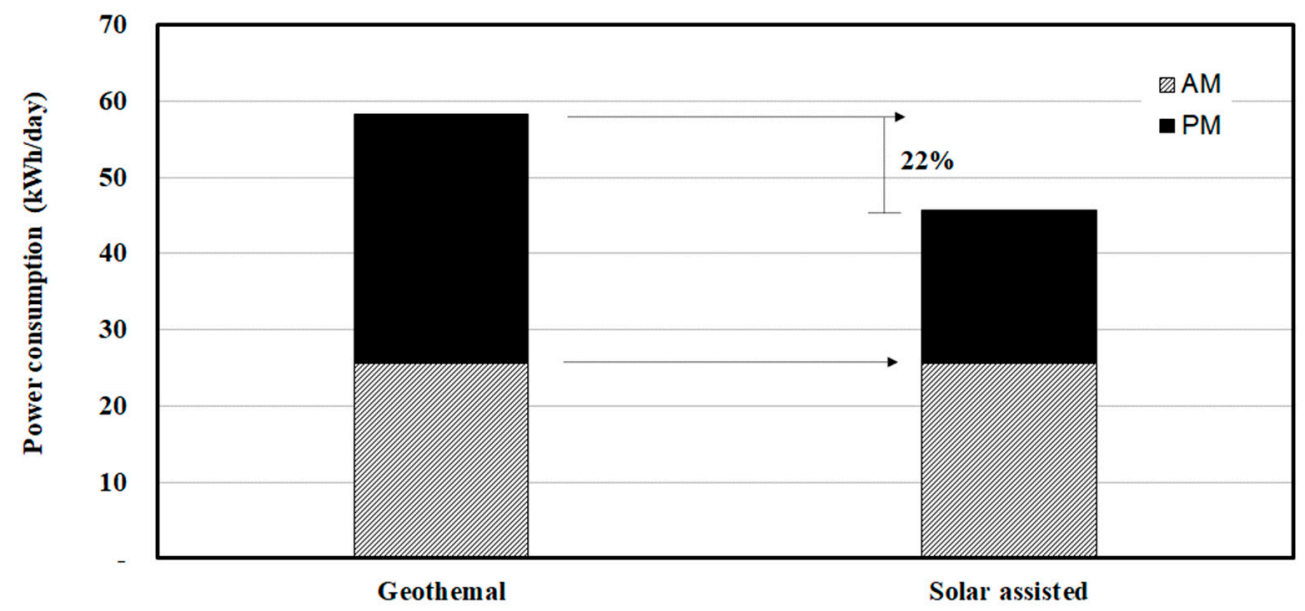

Figure 12. Averaged daily power consumption according to the operation modes.

\section{Conclusions}

In recent years, with the increase in zero-energy buildings in South Korea, geothermal source heat pump (GSHP) systems are being installed as a new type of a renewable energy system. However, the annual heating demand of South Korean buildings is larger than the cooling demand, and the heating performance of GSHPs decreases with time owing to thermal imbalances in the surrounding soil. To derive a more efficient system, a solarassisted GSHP was experimentally analyzed in this study. The performance of this system was analyzed for a period of 143 days from 15 November 2019 to 6 April 2020, and the findings of this study are as follows.

The performances of two GSHP systems, one with and one without a solar thermal collector, were compared by considering the operation results with similar outdoor temperature conditions. The heating COP of the geothermal-only operation was 5.4, whereas that of the solar-assisted operation was 7.0. A significant improvement in the heat pump performance was therefore demonstrated when the GSHP was connected to a solar thermal system. In addition, the power consumption for the system operation was reduced by about $20 \%$ compared with the GSHP-only system.

In the case of the GSHP-only system, the maximum temperature of the heat pump supply water on the heat source side was $13.1^{\circ} \mathrm{C}$ initially; however, it rapidly decreased to $11.4^{\circ} \mathrm{C}$ during operation. However, in the solar-assisted geothermal GSHP system, the supply water temperature to the heat pump heat source side was controlled between 15 and $20.9{ }^{\circ} \mathrm{C}$. Much higher temperatures could be supplied when solar heat was used instead of ground heat, and the solar heat contributes to the performance improvement of the heat pump system.

The COP variation with the supply temperature at the heat source side of the heat pump was analyzed; the COP of the heat pump almost linearly increased with an increase in the supply temperature. The COP of the heat pump ranged from 4.8 to 6.0 for the geothermal-only operation but improved to 5.4-7.4 for the solar-assisted operation.

The seasonal performance factor (SPF) for the heating period (140 days) showed that the SPF for the GHSP-only case was 4.1, while the SPF for the solar-assisted GSHP system was 4.9 . 
Comparisons were made for the average daily power consumption in the case of the geothermal-only and solar-assisted operation conditions. The results showed that the power consumption includes the consumption by the heat and circulation pumps showing a reduction by approximately $22 \%$ in the coupled operation of the solar thermal system.

In areas where a high heating load is required and the heating performance of GSHPs decrease with time owing to soil thermal imbalances, it is difficult to maintain high system performance. Consequently, the use of a solar thermal coupled heat pump system can be a good solution to guarantee better operation performance.

In future work, an optimal design and operation simulation analysis will be undertaken. In addition, a comprehensive analysis of the investment profitability of the optimization system will be conducted.

Author Contributions: Conceptualization, T.L.; Data curation, D.S., J.H.; Formal analysis, J.H.; Funding acquisition, T.L.; Investigation, J.H.; Methodology, J.H., T.L.; Project administration, D.S., T.L.; Resources, T.L., J.H.; Software, T.L., J.H.; Supervision, D.S., T.L.; Validation, D.S., J.H.; Visualization, D.S., J.H.; Writing—original draft, J.H.; Writing—review \& editing, D.S.,T.L., J.H. All authors have read and agreed to the published version of the manuscript.

Funding: This work was supported by the Urban Architecture Research Project (20AUDP-B09968606) funded by the Ministry of Land, Infrastructure and Transport in 2020.

Informed Consent Statement: Informed consent was obtained from all subjects involved in the study.

Data Availability Statement: Data available in a publicly accessible repository.

Conflicts of Interest: The authors declare no conflict of interest. The funders had no role in the design of the study; in the collection, analyses, or interpretation of data; in the writing of the manuscript, or in the decision to publish the results.

$\begin{array}{ll}\text { Abbreviations } \\ \text { COP } & \text { Coefficient Of Performance } \\ \text { SPF } & \text { Seasonal Performance Factor } \\ \mathrm{E} & \text { Electricity consumption }[\mathrm{kW}] \\ \mathrm{T}_{\mathrm{OA}} & \text { Outdoor Air Temperature }\left[{ }^{\circ} \mathrm{C}\right] \\ \mathrm{R}_{\mathrm{S}} & \text { Solar Radiation }\left[\mathrm{W} / \mathrm{m}^{2}\right] \\ \mathrm{T}_{\mathrm{S} \_H} & \text { Supply water Temperature for Heating } \\ \mathrm{T}_{\mathrm{R} \_H} & \text { Return water Temperature for Heating } \\ \mathrm{F}_{\mathrm{H}} & \text { Water Flow rate for Heating }\left[\mathrm{m}^{3} / \mathrm{h}\right] \\ \mathrm{F}_{\mathrm{HP}} \text { G } & \text { Water Flow rate for Heat Pump from Geothermal }\left[\mathrm{m}^{3} / \mathrm{h}\right] \\ \mathrm{F}_{\mathrm{HP}} \mathrm{S} & \text { Water Flow rate for Heat Pump from Solar collecting }\left[\mathrm{m}^{3} / \mathrm{h}\right] \\ \mathrm{T}_{\mathrm{S} \_H P} & \text { Supply water Temperature for Heat Pump }\left[{ }^{\circ} \mathrm{C}\right] \\ \mathrm{T}_{\mathrm{R} \_H P} & \text { Return water Temperature for Heat Pump }\left[{ }^{\circ} \mathrm{C}\right] \\ \mathrm{T}_{\mathrm{HT}} & \text { Water Temperature of the High-Level Heat storage Tank }\left[{ }^{\circ} \mathrm{C}\right] \\ \mathrm{T}_{\mathrm{LT}} & \text { Water Temperature of the Low-Level Heat storage Tank }\left[{ }^{\circ} \mathrm{C}\right] \\ \mathrm{T}_{\mathrm{S} \_S} & \text { Supply water Temperature for Solar collector }\left[{ }^{\circ} \mathrm{C}\right] \\ \mathrm{T}_{\mathrm{R} \_S} & \text { Return water Temperature for Solar collector }\left[{ }^{\circ} \mathrm{C}\right] \\ \mathrm{F}_{\mathrm{S}} & \text { Water Flow rate for Solar collector }\left[\mathrm{m}^{3} / \mathrm{h}\right]\end{array}$

\section{References}

1. Joo, B.K. Geothermal heating and cooling systems, initial investment and operating costs are excessively higher than gas heating and cooling systems. Gas News, 2020. Available online: http:/ /www.gasnews.com/news/articleView.html?idxno=91688 (accessed on 15 November 2020).

2. Sanner, B.; Karytsas, C.; Mendrinos, D. Current status of ground source heat pumps and underground thermal energy storage in Europe. Geothermics 2003, 32, 579-588. [CrossRef]

3. Hepbasli, A.; Akdemir, O.; Hancioglu, E. Experimental study of a closed loop vertical ground source heat pump system. Energy Convers. Manag. 2003, 44, 527-548. [CrossRef]

4. Kang, E.C. Invigorating the Geothermal Market, "Communal Housing” will be responsible for vitalizing the geothermal marker. Korea Heating Air-Conditioning \& Renewable News, 1 October 2015. Available online: http://www.kharn.kr/news/article.html?no= 392 (accessed on 15 November 2020).

5. Shahed, A.M.; Harrison, S.J. Preliminary review of geothermal solar assisted heat pumps. In Proceedings of the 4th Annual Canadian Solar Buildings Conference, Toronto, ON, Canada, 25-27 June 2009. 
6. Lohani, S.P.; Schmidt, D. Comparison of energy and exergy analysis of fossil plant, ground and air source heat pump building heating system. Renew. Energy 2010, 35, 1275-1282. [CrossRef]

7. Yu, T.; Liu, Z.; Chu, G. Influence of intermittent operation on soil temperature and energy storage duration of ground-source heat pump system for residential building. In Proceedings of the 8th International Symposium on Heating, Ventilation and Air Conditioning-Volume 2: HVACER Component and Energy System; Li, A., Zhu, Y., Li, Y., Eds.; Springer: Berlin/Heidelberg, Germany, 2014; pp. 203-213.

8. Qian, H.; Wang, Y. Modeling the interactions between the performance of ground source heat pumps and soil temperature variations. Energy Sustain. Dev. 2014, 23, 115-121. [CrossRef]

9. Retkowski, W.; Ziefle, G.; Thöming, J. Evaluation of different heat extraction strategies for shallow vertical ground-source heat pump systems. Appl. Energy 2015, 149, 259-271. [CrossRef]

10. Liu, Z.; Xu, W.; Qian, C. Investigation on the feasibility and performance of ground source heat pump (GSHP) in three cities in cold climate zone, China. Renew. Energy 2015, 84, 89-96. [CrossRef]

11. You, T.; Wu, W.; Wang, B.; Shi, W.; Li, X. Dynamic soil temperature of ground-coupled heat pump system in cold region. In Proceedings of the 8th International Symposium on Heating, Ventilation and Air Conditioning-Volume 2: HVACER Component and Energy System; Li, A., Zhu, Y., Li, Y., Eds.; Springer: Berlin/Heidelberg, Germany, 2014; pp. 439-448.

12. Dai, L.; Li, S.; DuanMu, L. Experimental performance analysis of a solar assisted ground source heat pump system under different heating operation modes. Appl. Eng. 2015, 75, 325-333. [CrossRef]

13. Shang, Y.; Dong, M.; Li, S. Intermittent experimental study of a vertical ground source heat pump system. Appl. Energy 2014, 136, 628-635. [CrossRef]

14. Tian, Y.; Wei, W.; Wenxing, S.; Baolong, W.; Xianting, L. An overview of the problems and solutions of soil thermal imbalance of ground-coupled heat pumps in cold regions. Appl. Energy 2016, 177, 515-536.

15. Ni, L.; Song, W.; Zeng, F.; Yao, Y. Energy saving and economic analyses of design heating load ratio of ground source heat pump with gas boiler as auxiliary heat source. In Proceedings of the 2011 International Conference on Electric Technology and Civil Engineering (ICETCE), Lushan, China, 22-24 April 2011; pp. 1197-1200.

16. Chen, X.; Yang, H.X.; Lu, L. Experimental studies on a ground coupled heat pump with solar thermal collectors for space heating. Energy 2011, 36, 5292-5300.

17. Korean Agency for Technology and Standards. Solar Thermal Collectors, KS B 8295. 2015; pp. 30-36. Available online: https: / / standard.go.kr/KSCI/standardIntro/getStandardSearchView.do? menuId=919\&topMenuId=502\&upperMenuId=50 $3 \& \mathrm{ksNo}=\mathrm{KSB} 8295 \& \mathrm{tmprKsNo}=\mathrm{KSB} 8295 \&$ re (accessed on 15 November 2020).

18. Khaled, Z.; Amenallah, G.; Ramzi, S.; Chakib, K. Solar thermal systems performances versus flat plate solar collectors connected in series. Engineering 2012, 4, 881-893.

19. Hong, P.J.; Seoung, L.W.; Kim, Y.K. The cooling seasonal performance factor of a hybrid ground-source heat pump with parallel and serial configurations. Appl. Energy 2013, 102, 877-884.

20. Lim, H.J. Performance evaluation and economic estimation of ground source heat pump cooling and heating system. J. Energy Eng. 2004, 13, 296-300. 